\title{
19: 63758298-63754746
}

National Cancer Institute

\section{Source}

National Cancer Institute. 19: 63758298-63754746. NCI Thesaurus. Code C41751.

Physical location of BC-2_Gene 